\title{
Tardigrades in Space Research - Past and Future
}

\author{
Erdmann Weronika ${ }^{1}$ - Kaczmarek Lukasz ${ }^{1}$
}

Received: 19 January 2014 / Accepted: 28 August 2016 /

Published online: 20 October 2016

(C) The Author(s) 2016. This article is published with open access at Springerlink.com

\begin{abstract}
To survive exposure to space conditions, organisms should have certain characteristics including a high tolerance for freezing, radiation and desiccation. The organisms with the best chance for survival under such conditions are extremophiles, like some species of Bacteria and Archea, Rotifera, several species of Nematoda, some of the arthropods and Tardigrada (water bears). There is no denying that tardigrades are one of the toughest animals on our planet and are the most unique in the extremophiles group. Tardigrada are very small animals (50 to 2,100 $\mu \mathrm{m}$ in length), and they inhabit great number of Earth environments. Ever since it was proven that tardigrades have high resistance to the different kinds of stress factors associated with cosmic journeys, combined with their relatively complex structure and their relative ease of observation, they have become a perfect model organism for space research. This taxon is now the focus of astrobiologists from around the world. Therefore, this paper presents a short review of the space research performed on tardigrades as well as some considerations for further studies.
\end{abstract}

Keywords Extreme conditions · Extremophiles · Space research · Space biology · Tardigrada · Water bears

\section{What are Tardigrades?}

Water bears (Tardigrada), discovered in 1773, are a phylum of small invertebrates belonging to the supertype Articulata. They can be found all over the Earth and can inhabit very diverse environments (from the deepest oceans to mountain tops). Water bears are small, cylindrical invertebrates, up to $2.1 \mathrm{~mm}$ in length, and are divided into five segments. The first segment

This paper is part of the Special Collection of Papers from EANA 2013: The 13th European Workshop on Astrobiology, 22-25 July 2013, Szczecin, Poland (Franco Ferrari and Ewa Szuszkiewicz Guest Editors)

Kaczmarek Łukasz

kaczmar@amu.edu.pl

Erdmann Weronika

weronika@erdmann.pl

1 Faculty of Biology, Department of Animal Taxonomy and Ecology, Adam Mickiewicz University in Poznań, Umultowska 89, 61-614 Poznań, Poland 
contains the head and the next four each have one pair of unsegmented legs ending (most often) in claws. The tardigrade body is covered with a flexible cuticle, which is smooth or covered with gibbosities, spines or plates. Despite being so small, they have a very complicated internal structure. Water bears have a complete digestive system adapted, depending on the species, to consume algae, bacteria, fungal cells or small invertebrates such as rotifers, nematodes and other tardigrades. They have a well developed nervous system consisting of rings around mouth (brain) and an abdominal chain with segmental ganglia. They also have various sensory organs like papilla, chemoreceptors and eyes. Water bears can be dioecious and bisexual; in the second case, sexual dimorphism is sometimes present (especially in Heterotardigrada). In many species, the phenomenon of parthenogenesis is also present. Fertilisation can be external or internal. The eggs are covered with an additional shell, the smooth or ornamented chorion, and are laid freely (directly into the environment) or in old exuviae. After hatching, tardigrades moult between two to seven times. The young resemble the adults, and they reach sexual maturity after the second or third moult, which takes several days. Adult tardigrades live approximately two to several months (Nelson et al. 2015). Currently, approximately 1,200 tardigrade species are known (Degma et al. 2009-2016; Vicente and Bertolani 2013), although it is estimated that the real number of species is much higher. At present, this phylum is divided into two classes, Eutardigrada and Heterotardigrada. Eutardigrada consists mainly of freshwater and terrestrial species (marine species are extremely rare). The body of eutardigrades is translucent or milky white (but sometimes has different colouration) and is covered with a flexible cuticle and devoid of plates. Among Heterotardigrada, both marine and terrestrial species are present. Their body is covered with a cuticle that produces various kinds of plates (Nelson 2002; Nelson et al. 2015).

\section{What Makes Them so Special?}

As mentioned above, tardigrades live not only in freshwater and marine environments but also in terrestrial habitats. Terrestrial species can be found in mosses, lichens and soil where they are threatened by drying. In this situation, terrestrial species need a thin water film around their bodies in order to stay active. These species have also developed a special skill that protects them against the effects of dehydration: the ability to enter into a cryptobiotic state. There are several types of cryptobiosis: a) anoxybiosis, a reaction to lack of sufficient oxygen, b) cryobiosis, a reaction to freezing temperatures, c) osmobiosis, a reaction to excessive salinity, and the best known type of cryptobiosis, d) anhydrobiosis, a reaction to a lack of liquid water in the environment (Kinchin 2008). In the anhydrobiotic state, the metabolic activity of tardigrades drops to a very low level (Pigoń and Węglarska 1955). This latent state can occur at the egg stage as well as in adults and can be repeated multiple times (Kinchin 2008). Anhydrobiosis gives tardigrades resistance to a lack of water, but also to a number of physical factors such as high temperature, radiation or different kinds of chemicals, such as ethanol, hydrogen sulphide and carbon dioxide (Kinchin 1994; Ramlov and Westh 2001; Wełnicz et al. 2011; Guidetti et al. 2012). Not all Tardigrada species show equal resistance to drying out, as there are differences in drying tolerance even between populations of the same species (Jönsson et al. 2001; Horikawa and Higashi 2004). The entrance into anhydrobiosis is preceded by a preliminary phase, during which the tardigrade body undergoes a series of metabolic and anatomical changes that are necessary to survive the unfavourable conditions. The changes are easiest to observe as a shrinkage of the body (forming numerous folds which 
reduce the body's surface area), namely the adoption of the tun formation (Baumann 1922). The tun form reduces the surface for evaporation and thus slows down the loss of liquid water (transpiration is reduced by about $50 \%$ ) (Wright 1989). The tun state also prevents the destruction of the internal and external organs during the drying process (Crowe 1975). When all free water evaporates from the tardigrade body, it begins the process of replacing the water bound to macromolecules. The lost water is replaced with bioprotectants such as trehalose, which protects macromolecules, such as nucleic acids and proteins, from losing their proper structure (Kinchin 2008). If the macromolecule structure is damaged, the cell dies. It is not certain how trehalose contributes to the protection of membrane proteins. It is also possible that the trehalose hydroxyl groups interact with hydrogen atoms replacing the same evaporating water (Kinchin 2008). In summary, trehalose is responsible for stabilising proteins, membrane lipids and nucleic acids (Webb 1964; Crowe 2002). However, it should be also emphasised that some tardigrades synthesise trehalose on a very low level (Wang et al. 2014). The other molecules involved in tardigrade cell protection during anhydrobiosis are LEA (late embryogenesis abundant), HSP (heat shock proteins), CAHS (cytoplasmic abundant heat soluble), SAHS (secretory abundant heat soluble) and aquaporin proteins (Förster et al. 2009; Yamaguchi et al. 2012; Grohme et al. 2013; Guidetti et al. 2011, 2012; Wełnicz et al. 2011). The LEA proteins have similar functions to trehalose, but in addition to protecting the cell membranes and proteins, they can also act as a hydration buffer and sequester ions. They can also be responsible for cell structure protection through renaturation of unfolded proteins (Tunnacliffe and Wise 2007). In turn, the HSPs could work as molecular chaperons (Goyal et al. 2005) and participate in protein folding, and inhibiting protein aggregation. So far, it has been proven that this type of protein (presumably the Hsp70-90 proteins family) are produced and stored in organisms going into anhydrobiosis, but their role during desiccation is still uncertain (Ramlov and Westh 2001; Reuner et al. 2010; Wełnicz et al. 2011). The CAHS and SAHS proteins probably form a molecular shield in water-deficient conditions (Yamaguchi et al. 2012). Aquaporin proteins may play a minor role during anhydrobiosis by fine-tuning water transport and greatly increasing membrane permeability (Grohme et al. 2013). Also, possession of the ROS (Reactive oxygen species) scavenging enzymes could represent a crucial strategy to avoid damages during desiccation in anhydrobiotic tardigrades (Rizzo et al. 2010; Rebecchi 2013). However, most of the bioprotectants and mechanisms that protect tardigrade cells during cryptobiosis are still poorly understood or completely unknown.

\section{Toughest Animals on Earth}

The ability to enter into a state of anhydrobiosis (which distinguishes water bears from most other organisms) lets tardigrades resist many unfavourable environmental factors (Rebecchi et al. 2007). Moreover, tardigrades are able to survive in an inactive form for many years (from nine to 20 years in natural conditions) (Guidetti and Jönsson 2002; Rebecchi et al. 2006; Guidetti et al. 2012). Interestingly, the death of individuals that are in a long anhydrobiotic state is mostly caused by the drying process itself and not by the aging process. This phenomenon can be explained by the so-called "Sleeping Beauty" model, first reported in rotifers (Ricci 2001; Segers and Shiel 2005). At the time when the model was confirmed for rotifers, this kind of shift in the age of anhydrobiotic animal was also supposed for tardigrades (Hengherr et al. 2008). On the other hand, it was also proven that during anhydrobiosis, cell damages accumulate with time (Rebecchi et al. 2009a). It is possible that such damages are accumulated in proportion to the time spent in anhydrobiosis and lead to animal death, even 
though desiccation itself does not seem to have an effect on tardigrade longevity and ageing (Guidetti et al. 2011). Water bears are also very resistant to extreme temperatures, and they can survive from $-272.8^{\circ} \mathrm{C}$ (Becquerel 1950) to about $150{ }^{\circ} \mathrm{C}$ (up to $15 \mathrm{~min}$ ) (Rahm 1923, 1924, 1926). Resistance to low temperatures was investigated repeatedly during research on anhydrobiosis and on cryobiosis. One of the first studies showed that many different species of Tardigrada withstand immersion in liquid air $\left(c a .-190^{\circ} \mathrm{C}\right)$, liquid nitrogen $\left(c a .-253^{\circ} \mathrm{C}\right)$ and liquid helium ( $c a .-272{ }^{\circ} \mathrm{C}$ ) (Rahm 1923, 1924, 1926). Other studies demonstrated that some species inhabiting the Arctic soil can survive up to six years ( 74 months) at $-80{ }^{\circ} \mathrm{C}$ (Newsham et al. 2006). These small invertebrates also exhibit significant resistance to low and high atmospheric pressures (from 200 to $280 \mathrm{hPa}$ to 7,500 MPa) (Jönsson et al. 2008; Ono et al. 2008). Tardigrades in an anhydrobiotic state are also resistant to high doses of ionising radiation and X-rays (ca. 5000 GY) (May et al. 1964; Horikawa et al. 2006). Some individuals are even able to survive very high doses of ultraviolet radiation (between 75 and $88 \mathrm{~kJ} \mathrm{~m}^{2}$ ) (Altiero et al. 2011). Water bears are resistant to physical stressors as well as some chemical stressors such as hydrogen sulphide, carbon dioxide, ethanol (for $c a .10 \mathrm{~min}$ ) and 1-hexanol (Baumann 1922; Ramlov and Westh 2001).

Unlike the other multicellular extremophiles, water bears are not only resistant in the anhydrobiotic state but also in the active state. Active tardigrades are able to survive in temperatures of about $38{ }^{\circ} \mathrm{C}$ ( $\mathrm{Li}$ and Wang 2005; Rebecchi et al. 2009b) and $-196{ }^{\circ} \mathrm{C}$ (Ramlov and Westh 2001). They also exhibit a significant resistance to high atmospheric pressures (up to $100 \mathrm{MPa}$ ) (Seki and Toyoshima 1998). It is also known that tardigrades in the active state are almost as resistant to radiation as in anhydrobiosis (Jönsson et al. 2005; Horikawa et al. 2006 2009; Altiero et al. 2011).

\section{Tardigrades in Space Research and Space Missions}

All of the above mentioned features of tardigrades caused scientists to consider them in the context of space research. In 1964, in the article "Actions différentielles des rayons x et ultraviolets sur le tardigrade Macrobiotus areolatus", it was suggested for the first time that tardigrades, due to their enormous resistance to radiation, could be model animals for space research (May et al. 1964). Thirty-seven years later, in the article "Tardigrades as a potential model organism in space research", Bertolani et al. (2001) suggested a similar concept. At the same time, studies focused on the phenomenon of cryptobiosis in tardigrades were conducted, revealing still greater resistance of this amazing animal to many unfavourable factors encountered in outer space. In 2007, Jönsson, based on knowledge resulting from these studies, showed that tardigrades can be suitable model organisms for astrobiological studies because of their ability to dehydrate, extreme temperature tolerance and radiation resistance (Jönsson 2007). Since that time, numerous articles suggesting that tardigrades can be used in space research have been published (Horikawa et al. 2008; Rebecchi et al 2010a). The latest paper from early 2012 indicated that tardigrades are an excellent model for space research (Guidetti et al. 2012). While that paper emphasises the previously known extraordinary resistance of tardigrades, it also suggests that there is a greater complexity to tardigrade organisms. The authors repeatedly emphasise that the complex structure of tardigrades allows extrapolation of the results of such studies to vertebrates (including humans). In conjunction with their small body size, their relative ease to culture and obtain offspring further enhances their importance as a potential model species (Guidetti et al. 2012). In 2008, Horikawa et al. proposed Ramazzottius varieornatus Bertolani \& Kinchin, 1993 as a model species in astrobiology 
research. In their paper they described a methodology for breeding this species under laboratory conditions. They also described the life history of this species and identified characteristics required to consider this particular species of tardigrade as a model (Horikawa et al. 2008). In the same year, it was also suggested that tardigrades could travel through space in a large meteorite and could probably confirm the theory of panspermia (Ono et al. 2008).

Based on researcher suggestions, a few space programmes focused on tardigrades were started and finished in recent years. In 2007, three projects were conducted during the FOTON-M3 mission studies. The Tardigrade Resistance to Space Effects (TARSE) Project was the first one involved in the mission of FOTON-M3. Its aim was to analyse the impact of environmental stress, life history traits and DNA damages in space (on board the spacecraft) on eutardigrade Paramacrobiotus richtersi (Murray, 1911). In this project active and anhydrobiotic tardigrades were exposed to radiation in microgravity conditions. Both active and inactive individuals had high survival rates with no induction of HSPs while showing an induction of the antioxidant response (Rebecchi et al. 2009c, 2010b, 2011a). The next project involved in the mission of FOTON-M3 was TARDIS (Tardigrada In Space). The main goal of this project was to check whether tardigrades from two species, Milnesium tardigradum Doyère, 1840 and Richtersius coronifer (Richters, 1903), were able to survive conditions of open space. The experiments showed that tardigrades can survive exposure to the space vacuum, but the addition of factors such as ultraviolet solar radiation, ionising solar radiation and galactic cosmic radiation significantly reduced their survival rate (Jönsson, et al. 2008). In the third project from the FOTON-M3 mission, RoTaRad (Rotifers, Tardigrades and Radiation), scientists examined effects on initial survival, long-term survival and fecundity of selected species of limno-terrestrial tardigrades in extreme stress conditions (mainly cosmic radiation) (Persson et al. 2011). Next was the Endeavour mission in 2011 and the project TARDIKISS (Tardigrades in Space). The main aim of this project was to broaden our knowledge of life history traits and mechanisms of repairing structural DNA damage during exposure to space flight stresses (Rebecchi et al. 2011b; Vukich et al. 2012). The first results showed that microgravity and cosmic radiation did not significantly affect the survival rate of tardigrades (Rebecchi et al. 2011b; Vukich et al. 2012). However, Rizzo et al. (2015) showed a significant difference in activities of ROS scavenging enzymes, the total content of glutathione and the fatty acid composition between tardigrades sent into space and control animals on Earth. The last space research project involving tardigrades was the Phobos Life Project. It was a part of the Phobos Ground Mission. The goal of this project was to study how the living organisms survive during space flight conditions. Scientists wanted to test the viability of selected organisms during an interplanetary flight lasting approximately 34 months and verify the theory of panspermia (http://www.forum.kosmonauta.net/index.php?topic=585.35; wap2). For this mission, the same organisms already used in other space experiments, and well-known to be radiation resistant, were used. They represented all three domains of life (Bacteria, Eukaryotes and Archaea). A total of 10 different taxa were used (species or strains), including three species of tardigrades: M. tardigradum, R. coronifer and Echiniscus testudo (Doyère, 1840). Unfortunately, the experiments were not successful because the spacecraft carrying the whole apparatus crashed and burned over the South Pacific Ocean on January 15th 2012.

\section{Further Perspectives}

As demonstrated above, we already know quite a lot on the limits of endurance of tardigrades regarding various stress factors. However, we still do not know the exact mechanisms of action 
that protect and repair their bodies in unfavourable conditions. The understanding of these mechanisms and knowledge of the responsible genes is an important step in astrobiological studies, especially if it can be extrapolated to vertebrates (including humans).

There are many possible future directions of astrobiological research regarding tardigrades. For example, one experiment could evaluate the ability of tardigrades to survive in a simulated atmosphere of certain celestial bodies in our solar system (such experiments simulating Martian conditions were conducted on bacteria, cyanobacteria, lichens and also tardigrades (Cockell 2005; Johnson et al. 2011; Rebecchi et al 2010b; Smith et al. 2009; Vera et al. 2010; 2014). This is interesting because a few of the celestial bodies in our solar system may periodically exhibit microenvironmental conditions appropriate for the survival of certain extremophiles. For example, it is well known that Martian soil contains water (Mitrofanov et al. 2014), and in some regions of Mars, in the summer periods, temperatures up to $20^{\circ} \mathrm{C}$ were recorded (NASA, official webpage). Even if all environmental conditions are not entirely favourable for life, tardigrades are quite resistant in both the anhydrobiotic and the active state. Moreover, organisms which provide nourishment for tardigrades (e.g. bacteria, algae, rotifers or nematodes) are just as resistant as water bears (Guidetti and Jönsson 2002; Rettberg et al. 2002; Islam and Schulze-Makuch 2007; Meeßen et al. 2013). However, these relatively beneficial life periods are interrupted by periods of very unfavourable conditions for living organisms. This is where cryptobiosis has a potential and very important role. The ability to enter into cryptobiosis is helpful not only for travelling for long cosmic distances, but also for providing a possibility of surviving long periods when environmental conditions are unfavourable. This could enable researchers to determine whether tardigrades can survive and live on other planets in the solar system or on their moons. We should also continue studies on tardigrade resistance to combined stress conditions such as the combined effects of cosmic radiation and microgravity, or low temperature and the presence of harmful chemicals. Such studies would help determine the limits of survival of Earth's multicellular organisms. This is very interesting especially in the context of searching for life on other planets and moons.

Acknowledgments The studies were conducted in the framework of activities of the BARg (Biodiversity and Astrobiology Research group). The authors also wish to thank Cambridge Proofreading LLC (http://proofreading.org/) and Proof-Reading-Service.com (http://www.proof-reading-service.com/en/) for help in improving the English in the manuscript.

Open Access This article is distributed under the terms of the Creative Commons Attribution 4.0 International License (http://creativecommons.org/licenses/by/4.0/), which permits unrestricted use, distribution, and reproduction in any medium, provided you give appropriate credit to the original author(s) and the source, provide a link to the Creative Commons license, and indicate if changes were made.

\section{References}

Altiero T, Guidetti R, Caselli V, Cesari M, Rebecchi L (2011) Ultraviolet-B radiation tolerance in hydrated and desiccated eutardigrades. J Zool Syst Evol Res 49:104-110

Baumann H (1922) Die Anabiose der Tardigraden. Zool Jahrb 45:501-556

Becquerel P (1950) La suspension de la vie au desessous de 1/20 K absolu par demagnetisation adiabatique de l'alun de fer dans le vide les plus elève. C R Acad Séan Paris 231:261-263

Bertolani R, Rebecchi L, Jönsson KI, Borsari S, Guidetti R, Altiero T (2001) Tardigrades as a model for experiences of animal survival in the space. In: Monti, R., Bonifazi, C. (Eds.), La Scienza e la Tecnologia Spaziale sulla Stazione Internazionale (ISS). Spec. Issue ASI Natl. Workshop, Turin, 2001. MSSU-Micro Space Station Util 2:211-212

Cockell CS, Schuerger AC, Billi D, Friedmann EI, Panitz C (2005) Effects of a simulated Martian UV flux on the cyanobacterium, Chroococcidiopsis sp. 029. Astrobiol 5:127-140 
Crowe J (1975) The physiology of cryptobiosis in tardigrades. Mem Ist Ital Idrobiol 32 suppl.: 37-59

Crowe LM (2002) Lessons from nature: the role of sugars in anhydrobiosis. Comp Biochem Physiol A Mol Integr Physiol 13:505-513

de JP V, Schulze-Makuch D, Khan A, Lorek A, Koncz A, Möhlmann D, Spohn T (2014) Adaptation of an Antarctic lichen to Martian niche conditions can occur within 34 days. Planet Space Scie 98:182-190

de Vera JP, Möhlmann D, Butina F, Lorek A, Wernecke R, Ott S (2010) Survival potential and photosynthetic activity of lichens under Mars-like conditions: a laboratory study. Astrobiol 10(2):215-27. doi:10.1089 /ast.2009.0362

Degma P, Bertolani R, Guidetti R (2009-2016) Actual checklist of Tardigrada species. 2009-2016, Ver. 30: 1509-2016 http://www.tardigrada.modena.unimo.it/miscellanea/Actual\%20checklist\%20of\%20Tardigrada.pdf

Förster F, Liang C, Shkumatov A, Beisser D, Engelmann JC, Schnölzer M, Frohme M, Müller T, Schill RO, Dandekar T (2009) Tardigrade workbench: comparing stress-related proteins, sequence-similar and functional protein clusters as well as RNA elements in tardigrades. BMC Genomics 10:469. doi:10.1186/14712164-10-469

Goyal K, Walton LJ, Browne JA, Burnell AM, Tunnacliffe A (2005) Molecular anhydrobiology: identifying molecules implicated in invertebrate anhydrobiosis. Integr Comp Biol 45:702-709

Grohme MA, Mali B, Wełnicz W, Michel S, Schill RO, Frohme M (2013) The aquaporin channel repertoire of the tardigrade Milnesium tardigradum. Bioinform Biol Insights 7:153-165. doi:10.4137/BBI.S11497

Guidetti R, Jönsson KI (2002) Long-term anhydrobiotic survival in semi-terrestrial micrometazoans. J Zool 257:181-187

Guidetti R, Altiero T, Rebecchi L (2011) On dormancy strategies in tardigrades. J Insect Physiol 57(5):567-576

Guidetti R, Rizzo AM, Altiero T, Rebecchi L (2012) What can we learn from the toughest animals of the Earth? Water bears (tardigrades) as multicellular model organisms in order to perform scientific preparations for lunar exploration. Planet Space Scie 74(1):97-102

Hengherr S, Brümmer F, Schill RO (2008) Anhydrobiosis in tardigrades and its effects on longevity traits. J Zool 275:216-220

Horikawa DD, Higashi S (2004) Desiccation tolerance of the tardigrade Milnesium tardigradum collected in Sapporo, Japan and Bogor, Indonesia. Zool Sci 21:813-816

Horikawa DD, Sakashita T, Katagiri C, Watanabe M, Kikawada T, Nakahara Y, Hamada N, Wada S, Funayama T, Higashi S, Kobayashi Y, Okuda T, Kuwabara M (2006) Radiation tolerance in the tardigrade Milnesium tardigradum. Int J Radiat Biol 82:843-848

Horikawa DD, Kunieda T, Abe W, Watanabe M, Nakahara Y, Yukuhiro F, Sakashita T, Hamada N, Wada S, Funayama T, Katagiri C, Kobayashi Y, Higashi S, Okuda T (2008) Establishment of a rearing system of the extremotolerant tardigrade Ramazzottius varieornatus: a new model animal for astrobiology. Astrobiol 6(3): 549-556

Horikawa DD, Iwata K, Kawai K, Koseki S, Okuda T, Yamamoto K (2009) High hydrostatic pressure tolerance of four different anhydrobiotic animal species. Zool Sci 26:238-242

Islam MR, Schulze-Makuch D (2007) Adaptations to environmental extremes by multicellular organisms. Int J Astrobiol 6(3):199-215

Johnson AP, Pratt LM, Vishnivetskaya T, Pfiffner S, Bryan RA, Dadachova E, Whyte L, Radtke K, Chan E, Tronick S, Borgonie G, Mancinelli RM, Rothshchild LJ, Rogoff DA, Horikawa DD, Onstott TC (2011) Extended survival of several organisms and amino acids under simulated Martian surface conditions. Icarus 211(2):1162-1178

Jönsson KI (2007) Tardigrades as a potential model organism in space research. Astrobiol 7(5):757-766

Jönsson KI, Borsari S, Rebecchi L (2001) Anhydrobiotic survival in populations of the tardigrades Richtersius coronifer and Ramazzottius oberhaeuseri from Italy and Sweden. Zool Anz 240:419-423

Jönsson KI, Harms-Ringdhal M, Torudd J (2005) Radiation tolerance in the eutardigrade Richtersius coronifer. Int J Radiation Biol 81:649-656

Jönsson KI, Rabbow E, Schill RO, Harms-Ringdahl M, Rettberg P (2008) Tardigrades survive exposure to space in low Eart orbit. Curr Biol 18:729-731

Kinchin IM (1994) The biology of tardigrades. Portland Press, London, pp 1-186

Kinchin IM (2008) Tardigrades and anhydrobiosis water bears and water loss. Biochem 30(4):18-20

Li X, Wang L (2005) Effect of thermal acclimation on preferred temperature, avoidance temperature and lethal thermal maximum of Macrobiotus harmsworthi Murrray (Tardigrada, Macrobiotidae). J Therm Biol 30:443-448

May RM, Maria M, Guimard J (1964) Actions différentielles des rayons x et ultraviolets sur le tardigrade Macrobiotus areolatus, a l'état et desséché. Bull Biol France Belgique 98:349-367

Meeßen J, Sánchez FJ, Brandt A, Balzer E-M, de la Torre R, Sancho LG, de Vera J-P, Ott S (2013) Extremotolerance and resistance of lichens: comparative studies on five species used in astrobiological research I. Morphological and anatomical characteristics. Orig Life Evol Biosph 43:283-303

Mitrofanov IG, Litvak ML, Sanin AB, Starr RD, Lisov DI, Kuzmin RO, Behar A, Boynton WV, Hardgrove C, Harshman K, Jun I, Milliken RE, Mischna MA, Moersch JE, Tate CG (2014) Water and chlorine content in 
the martian soil along the first $1900 \mathrm{~m}$ of the curiosity rover traverse as estimated by the DAN instrument. J Geophys Res: Planets 119(7):1579-1596

Nelson DR (2002) Current status of the tardigrada. Evolution and ecology. Integr Comp Biol 42:652-659

Nelson DR., Guidetti R, Rebecchi L (2015) Phylum Tardigrada. In: Thorp JH; Rogers DC (ed) Thorp and Covich's freshwater invertebrates, 4th edn. Ecology And General Biology, vol I, p: 347-380

Newsham K, Maslen N, Melnnes S (2006) The biology and ecology of lotic Tardigrada. Freshwater Biol 44:101-102

Ono F, Saigusa M, Uozumi T, Matsushima Y, Ikeda H, Saini NL, Yamashita M (2008) Effect of high hydrostatic pressure on to life of the tiny animal tardigrade. J Phys Chem Solids 69:2297-2300

Persson D, Halberg KA, Jorgensen A, Ricci C, Mobjerg N, Kristensen RM (2011) Extreme stress tolerance in tardigrades: surviving space conditions in low earth orbit. J Zool Syst Evol Res 49(Suppl. 1): 90-97

Pigoń A, Weglarska B (1955) Rate of metabolism in tardigrades during active life and anabiosis. Nature 176:121-122

Rahm PG (1923) Biologische und Physiologische Beiträge zur Kenntnis der Moosfauna. Z Alg Physiol 20:1-34

Rahm PG (1924) Weitere physiologische Versuche mit niederen Temperaturen Ein Beitrag zur Lösung des Kalteproblems. Verh dtsch zool Ges 29:106-111

Rahm PG (1926) Die Trochenstarre (Anabiose) de moostierwelt (ihr Verlauf. ihre Bedeutung und ihr Unterschied on der Cystebildung). Biol Zbl 46:452-477

Ramlov H, Westh P (2001) Cryptobiosis in the Eutardigrade Adorybioltus (Richtersius) cornifer. Tolerance to alcohols, temperature and de novo protein synthesis. Zool Anz 240:521-522

Rebecchi L (2013) Dry up and survive: the role of antioxidant defences in anhydrobiotic organism. J Limnol 72(s1):62-72

Rebecchi L, Guidetti R, Borsari S, Altiero T, Bertolani R (2006) Dynamics of long-term anhydrobiotic survival of lichen-dwelling tardigrades. Hydrobiol 558:23-30

Rebecchi L, Altiero T, Guidetti R (2007) Anhydrobiosis: the extreme limit of desiccation tolerance. Invertebr Surv J 4:65-81

Rebecchi L, Cesari M, Altiero T, Frigieri A, Guidetti R (2009a) Survival and DNA degradation in anhydrobiotic tardigrades. J Exp Biol 212:4033-4039

Rebecchi L, Boschini D, Cesari M, Lencioni V, Bertolani R, Guidetti R (2009b) Stress response of a boreo-alpine species of tardigrade, Borealibius zetlandicus (Eutardigrada, Hypsibiidae). J Limnol 68:64-70

Rebecchi L, Altiero T, Guidetti R, Cesari M, Bertolani R, Negroni M, Rizzo AM (2009c) Tardigrade resistance to space effects: first results of experiments on the LIFE-TARSE mission on FOTON-M3. Astrobiol 9:581-591

Rebecchi L, Altiero T, Galletta G, Cesari M, D’Alessandro M, Bertolani R, Guidetti R (2010a) Tardigrade survival under Martian conditions. Abstract book of the 31 st Annual ISGP Meeting, 11 th ESA Life Sciences Symposium, 5 th ISSBB Symposium, ELGRA Symposium "Life in Space for Life on Earth" Trieste, $122-123$

Rebecchi L, Altiero T, Guidetti R, Cesari M, Bertolani R, Rizzo AM, Negroni M (2010a) Resistance to extreme stresses in the Tardigrada: experiments on Earth and in Space and astrobiological perspectives. Astrobiol Sci Conf 2010

Rebecchi L, Altiero T, Guidetti R, Caselli V, Cesari M (2011a) Resistance of the anhydrobiotic eutardigrade Paramacrobiotus richtersi to space flight (LIFE- TARSE mission on FOTON-M3). J Zool Syst Evol Res 49(Suppl. 1): 1-132

Rebecchi L., Altiero T, Cesari M., Marchioro T, Giovannini I, Rizzo AM, Ganga PL, Vikich, M, Donati A, Zolesi V, Bertolani R, Guidetti R. (2011b) TARDIKISS: tardigrades in the mission STS-134, the last of the shuttle Endeavour. Abstract of V National meeting of ISSBB: Spazio, la Nuova Frontiera per l'Umanita, Padova 17

Rettberg P, Rabbow E, Panitz C, Reitz G, Horneck G (2002) Survivability and protection of bacterial spores in space - The BIOPAN experiments. Proceedings of the Second European Workshop on Exo-Astrobiology; Graz; Austria, European Space Agency, (Special Publication) 518: 105-108

Reuner A, Hengherr S, Mali B, Förster F, Arndt D, Reinhardt R, Dandekar T, Frohme M, Brümmer F, Schill RO (2010) Stress response in tardigrades: differential gene expression of molecular chaperones. Cell Stress and Chaperones 15:423-430

Ricci C (2001) Dormancy patterns in rotifers. Hydrobiol 446(447):1-11

Rizzo AM, Negroni M, Altiero T, Montorfano G, Corsetto P, Berselli P, Berra B, Guidetti R, Rebecchi L (2010) Antioxidant defences in hydrated and desiccated states of the tardigrade Paramacrobiotus richtersi. Comp Biochem Physiol 156(2):115-121

Rizzo AM, Altiero T, Corsetto PA, Montorfano G, Guidetti R, Rebecchi L (2015) Space flight effects on antioxidant molecules in dry tardigrades: The TARDIKISS experiment. BioMed Res Int 167642:1-7. doi:10.1155/2015/167642

Segers H, Shiel RJ (2005) Tale of a sleeping beauty: a new and easily cultured model organism for experimental studies on bdelloid rotifers. Dev Hydrobiol 181:141-145

Seki K, Toyoshima M (1998) Preserving tardigrades under pressure. Nature 395:853-854 
Smith DJ, Schuerger AC, Davidson MM, Pacala SW, Bakermans C, Onstott TC (2009) Survivability of Psychorobacter cryohalolentis K5 under simulated Martian surface conditions. Astrobiol 9(2):1-8

Tunnacliffe A, Wise MJ (2007) The continuing conundrum of the LEA proteins. Naturwissenschaften 94:791-812

Vicente F, Bertolani R (2013) Considerations on the taxonomy of the Phylum Tardigrada. Zootaxa 3626:245-248

Vukich M, Ganga PL, Cavalieri D, Rivero D, Pollastri S, Mugnai S, Mancuso S, Pastorelli S, Lambreva M, Antonacci A, Margonelli A, Bertalan I, Johan- Ningmeier U, Giardi MT, Rea G, Pugliese M, Quarto M, Roca V, Zanin A, Borla O, Rebecchi L, Altiero T, Guidetti R, Cesari M, Marchioro T, Bertolani R, Pace E, De Sio A, Casarosa M, Tozzetti L, Branciamore S, Gallori E, Scarigella M, Bruzzi M, Bucciolini M, Talamonti C, Donati A, Zolesi V (2012) BIOKIS: a model payload for multisciplinary experiments in microgravity. Microgravity Sci Technol 24(6):397-409

Wang C, Grohme MA, Mali B, Schill RO, Frohme M (2014) Towards decrypting cryptobiosis - analyzing anhydrobiosis in the tardigrade Milnesium tardigradum using transcriptome sequencing. PLoS ONE 9(3), e92663. doi:10.1371/journal.pone.0092663

Webb SJ (1964) Bound water, metabolites and genetic continuity. Nature 203:374-377

Welnicz W, Grohme MA, Kaczmarek Ł, Schill RO, Frohme M (2011) Anhydrobiosis in tardigrades - the last decade. J Insect Physiol 57(5):577-583

Wright JC (1989) Desiccation tolerance and water retentive mechanisms in tardigrades. J Exp Biol 142:267-292

Yamaguchi A, Tanaka S, Yamaguchi S, Kuwahara H, Takamura C, Imajoh-Ohmi S, Horikawa DD, Toyoda A, Katayama T, Arakawa K, Fujiyama A, Kubo T, Kunieda T (2012) Two novel Heat-Soluble protein families abundantly expressed in an anhydrobiotic tardigrade. PLoS ONE 7(8), e44209. doi:10.1371/journal. pone.0044209 